\title{
UJI EFEKTIVITAS FORMULASI SEDIAAN KRIM EKSTRAK KULIT BUAH PISANG GOROHO (Musa acuminafe L.) TERHADAP BAKTERI Staphylococcus aureus
}

\author{
THE EFFECTIVENESS TEST FORMULATION OF GOROHO BANANA \\ (Musa acuminafe L.) PEEL EXTRACT CREAM ON Staphylococcus aureus BACTERIA
}

\author{
Stephany P. Pangemanan ${ }^{1)}$, Hosea J. Edy ${ }^{1)}$, Erladys M. Rumondor ${ }^{1)}$ \\ 1) Program StudiFarmasi FMIPA UNSRAT Manado, 95115 \\ *stephanyputri27@gmail.com
}

\begin{abstract}
Goroho Banana Skin (Musa acuminafe L.) is a plant that contains flavonoid compounds, saponins and tannins that can inhibit bacterial growth. This study aims to test the antibacterial effectiveness of ethanol extract cream of goroho banana peel and evaluate the preparations using parameters of physical properties and physical stability. This research uses laboratory experimental methods. Cream formula is made with a variety of ethanol extract concentrations of Goroho Banana peel 2.5\%, 5\%, 7.5\%, 10\%, 12.5\%. Goroho Banana peel extract was obtained by maceration using $96 \%$ ethanol solvent. The study of antibacterial test of ethanol extract of Goroho Banana peel using wells method on Staphylococcus aureus bacteria resulted in inhibition of $7.03 \pm$ $3.29 \mathrm{~mm}$ at a concentration of $12.5 \%$. All tests are carried out before and during the cycling test. The results obtained before and during the cycling testshowed that the cream preparations met organoleptic requirements, homogeneity, cream pH 6.807 (4.5-6.5), cream adhesion 9.63 seconds (<4 seconds), cream spread 4, $53 \mathrm{~cm}$ (5$7 \mathrm{~cm})$. It can be concluded that the ethanol extract of Goroho Banana peel cream meets stable physical test parameters and has moderate antibacterial activity.
\end{abstract}

Keywords: Goroho Banana Peel (Musa acuminafe L.), Antibacterial, Cream.

\begin{abstract}
ABSTRAK
Kulit Buah Pisang Goroho (Musa acuminafe L.) merupakan tanaman yang mengandung senyawa flavonoid, saponin dan tannin yang mampu menghambat pertumbuhan bakteri. Penelitian ini bertujuan untuk menguji efektivitas antibakteri sediaan krim ekstrak etanol kulit buah pisang goroho dan mengevaluasi sediaan dengan menggunakan parameter uji sifat fisik dan stabilitas fisik. Penelitian ini menggunakan metode eksperimental laboratorium, Formula sediaan krim dibuat dengan variasi konsentrasi ekstrak etanol kulit buah Pisang Goroho 2,5\%, 5\%, 7,5\%, 10\%, 12,5\%. Ekstrak kulit buah Pisang Goroho diperoleh dengan cara maserasi menggunakan pelarut etanol 96\%. Penelitian uji antibakteri sediaan krim esktrak etanol kulit buah Pisang Goroho menggunakan metode sumuran pada bakteri Staphylococcus aureus menghasilkan daya hambat 7,03 $\pm 3,29 \mathrm{~mm}$ pada konsentrasi $12,5 \%$. Semua pengujian dilakukan sebelum dan selama cycling test. Hasil penelitian yang didapat sebelum dan selama cycling test menunjukkan bahwa sediaan krim memenuhi persyaratan organoleptis, homogenitas, $\mathrm{pH}$ krim 6,807 (4,5-6,5), daya lekat krim 9,63 detik ( $<4$ detik), daya sebar krim 4,53 cm $(5-7 \mathrm{~cm})$. Dapat disimpulkan bahwa sediaan krim ekstrak etanol kulit buah Pisang Goroho memenuhi parameter uji fisik stabil dan memiliki aktivitas antibakteri yang sedang.
\end{abstract}

Kata kunci : Kulit Buah Pisang Goroho (Musa acuminafe L.), Antibakteri, Krim. 


\section{PENDAHULUAN}

Indonesia merupakan negara yang terletak di daerah khatulistiwa, yang memiliki suhu kamar berkisar $25-30^{\circ} \mathrm{C}$ ini merupakan negara yang berpotensi menjadi tempat yang subur untuk pertumbuhan bakteri dan jamur. Sebagian besar mikroorganisme ini bersifat patogen pada manusia, yang menyebabkan manusia sebagai inang mengalami infeksi dari mulai keadaan akut sampai kronis, salah satunya merupakan penyakit yang di sebabkan oleh infeksi bakteri Staphylococcus aureus. Jenis bakteri ini diketahui merupakan bakteri fakultatif anaerob yang menjadi faktor predisposisi dalam berbagai penyakit, dapat menimbulkan penyakit melalui kemampuan berkembang biak dan menyebar luas dalam jaringan melalui pembentukan berbagai zat ekstraseluler berupa enzim dan toksin seperti katalase, koagulase, eksotoksin dan enterotoksin. Bakteri ini sering ditemukan secara alami di kulit dan nasofaring pada tubuh manusia, jika Staphylococcus aureus menyebar dan menjadi bakterimia, dapat terjadi endokarditis, osteomilitis akut, hematogen, meningitis atau infeksi paru-paru (Tina et al, 2009).

Saat ini, telah dikembangkan penelitian mengenai efektivitas antibakteri menggunakan bahan herbal yang dapat menggantikan obat kimia, salah satunya yang telah teruji mengandung zat yang dapat menghambat bakteri ialah flavonoid pada buah pisang goroho. Buah pisang goroho merupakan salah satu buah khas di Sulawesi Utara yang banyak digunakan masyarakat baik dikonsumsi langsung atau sebagai bahan olahan makanan. Semua bagian dari pohon pisang memiliki potensi antibakteri (Kinho et al, 2011).

Penelitian yang dilakukan oleh (Kurniawan et al, 2013), melaporkan bahwa getah kulit buah pisang goroho memiliki kandungan fitokimia seperti flavonoid, saponin dan tanin. Senyawa tersebut dipercaya dapat menghambat pertumbuhan bakteri. Sampai saat ini, penelitian tentang ekstrak kulit buah pisang goroho untuk menghambat bakteri Staphylococcus aureus belum pernah dilakukan. Berdasarkan penelitian kulit buah Pisang Goroho mengandung senyawa fenolik, flavonoid dan tanin. Ekstrak kulit Pisang Goroho memiliki aktivifitas sebagai penangkal radikal bebas yang tertinggi pada ekstrak etanol sebesar $75,71 \%$ dan untuk nilai SPFnya 16,63 (Alhabsyi et al, 2014).

Berdasarkan latar belakang diatas, peneliti tertarik untuk melakukan penelitian tentang pembuatan sediaan krim. Krim dipilih karena merupakan salah satu bentuk sediaan topikal umumnya yang digunakan untuk terapi yang bersifat lokal (Nugroho, 2015).

Bentuk sediaan krim lebih disukai oleh masyarakat karena mudah dibersihkan dan mudah menyebar. Penggunaan sediaan krim juga dapat memberikan efek dingin, mengkilap dan melembabkan kulit. Sediaan krim tipe M/A dibuat dengan cara mendispersikan minyak dan air. Keunggulan krim tipe M/A yaitu memberikan efek yang optimum karena mampu menaikkan gradien konsentrasi zat aktif yang menembus kulit sehingga absorbsi perkutan menjadi meningkat (Engelina, 2013).

\section{METODOLOGI PENELITIAN Waktu dan Tempat Penelitian}

Penelitian dilaksanakan pada bulan Desember 2019 - Juni 2020 di Laboratorium Farmasi Lanjutan, Program Studi Farmasi, Fakultas Matematika dan Ilmu Pengetahuan Alam, Universitas Sam Ratulangi, Manado.

\section{Alat dan Bahan}

Peralatan yang digunakan dalam penelitian ini ialah oven, timbangan analitik, blender, batang pengaduk, gelas ukur, corong, gelas kimia, kamera, label, hot plate, inkubator, (Laminari Air Flow) LAF, cawan petri, pH meter, autoklaf, erlenmeyer, tabung reaksi, mistar, wadah krim, wadah ekstrak, dan ayakan.

Bahan yang digunakan dalam penelitian ini ialah kulit buah pisang goroho, etanol 96\%, Nutrien Agar (NA), asam stearat, TEA, parafin cair, setil alkohol, gliserin, aquades, bakteri Staphylococccus aureus.

\section{Prosedur Penelitian \\ Persiapan sampel}

Kulit buah pisang Goroho digunakan sebanyak 8500 gram yang kemudian dicuci dengan air mengalir, dirajang, dan dikeringkan dalam ruangan. Sampel selanjutnya diblender dan diayak hingga menjadi simplisia (Edy et al, 2019).

\section{Pembuatan Ekstrak}

Kulit buah pisang Goroho diekstrak dengan menggunakan metode maserasi dengan pelarut etanol $96 \%$. Proses maserasi dilakukan selama 5 hari hingga didapat filtrat 1 dan ampas 1 . Ampas 1 kemudian dilakukan remaserasi selama 3 hari hingga didapat filtrat 2 dan ampas 2. Filtrat 1 dan filtrat 2 dicampurkan dan diuapkan menggunakan oven hingga diperoleh ekstrak kental (Edy et al, 2019). 


\section{Formulasi krim}

Basis krim tipe M/A yang dibuat terdiri dari dua fase yaitu fase minyak (parafin cair, setil alkohol, asam stearat) dan fase air (TEA, gliserin). Fase - fase tersebut dipanaskan pada suhu $60^{\circ}-70^{\circ} \mathrm{C}$ ditangas air. Fase minyak dipindahkan kedalam lumpang dan yang telah berisi fase air, kemudian diaduk sampai homogen hingga terbentuk massa krim.

\section{Uji Aktivitas Antibakteri}

Uji aktivitas anti bakteri menggunakan metode difusi agar (difusi kirby dan baeur yang dimodifikasi) dengan cara sumuran yang terdiri dari 2 lapisan media agar. Lapisan agar yang pertama dibuat dengan menuangkan $50 \mathrm{ml}$ NA ke dalam cawan petri, dibiarkan memadat dan ditanamkan pencadang. Lapisan agar yang kedua dibuat dengan menuangkan masingmasing $50 \mathrm{ml} \mathrm{NA}$ yang sudah ditambahkan suspense bakteri kedalam cawan petri dan dibiarkan memadat. Pencandang diangkat secara aseptic menggunakan pinset dari masing-masing cawan petri, sehingga terbentuk sumur-sumur . Sebanyak 0,1 gram krim masing-masing konsentrasi, kontrol positif (krim gentamicin) dan kontrol negatif (basis krim) dimasukkan kedalam sumur yang berbeda. Dilakukan inkubasi pada suhu $37^{\circ} \mathrm{C}$ selama 24 jam lalu diamati zona bening yang terbentuk.

\section{Evaluasi Sifat Fisik Krim}

\section{a. Organoleptis}

Pemeriksaan organoleptis meliputi bentuk, warna dan bau yang diamati secara visual. Spesifikasi krim yang harus dipenuhi adalah memiliki konsistensi lembut, warna sediaan homogen, dan harum (Erawati et al., 2016).

\section{b. Uji daya lekat}

Pengujian daya lekat sediaan dilakukan dengan cara krim diletakkan pada satu sisi kaca objek dengan sisi bawahnya telah dipasangkan tali untuk mengikat beban. Kemudian ditempelkan pada kaca objek yang lain. Beban yang digunakan adalah $50 \mathrm{~g}$. Kemudian diamati waktu yang dibutuhkan beban tersebut untuk memisahkan kedua kaca tersebut.

c. Uji pH

Krim pada masing-masing tipe dan konsentrasi disiapkan, kemudian diukur pHnya menggunakan $\mathrm{pH}$ Universal dan selanjutnya dilihat perubahan warna yang terjadi. Dicatat nilai $\mathrm{pH}$ masing-masing formula. Nilai $\mathrm{pH}$ yang ideal yaitu 4,5-6,5 (Simangunsong et al., 2018). d. Uji daya sebar

Ditimbang 1 gram krim, diletakkan ditengah cawan petri yang berada pada posisi terbalik. Diletakkan sekeping kaca objek transparan yang lain diatas krim, dibiarkan 1 menit. Kemudian ditambahkan beban 200 gram beban tambahan, didiamkan 1 menit. Dicatat diameter krim yang menyebar.

e. Uji Homogenitas

Pemeriksaan homogenitas dilakukan untuk melihat tercampurnya bahan-bahan sediaan krim. Sebanyak 1 gram krim dioleskan pada sekeping kaca transparan. Kemudian diamati sediaan harus menunjukan susunan yang homogen dan tidak terlihat adanya butiran kasar (Lubis et $a l, 2012$ ).

f. Stabilitas

Uji stabilitas atau cycling test ini merupakan salah satu cara mempercepat evaluasi kestabilan fisik yang dilakukan sebanyak 6 siklus. Krim disimpan pada suhu dingin $\pm 4^{\circ} \mathrm{C}$ selama 24 jam lalu dikeluarkan dan ditempatkan pada suhu $\pm 40^{\circ}$ Cselama 24 jam (1 siklus). Kondisi fisik krim yaitu organoleptik, homogenitas, $\mathrm{pH}$, daya sebar dan daya lekat selama cycling test dibandingkan dengan hasil sebelumnya (Dewi, 2010).

\section{HASIL DAN PEMBAHASAN}

\section{Ekstraksi}

Proses ekstraksi menggunakan metode ekstraksi cara dingin, yaitu maserasi menggunakan $3800 \mathrm{~mL}$ pelarut etanol 96\%, proses maserasi dilakukan selama 4 hari dan diremaserasi selama 2 hari hingga diperoleh ekstrak kental sebanyak 50,4 g. Rendemen yang diperoleh $7,2 \% \mathrm{~b} / \mathrm{v}$.

\section{Formulasi Krim}

Formula krim ekstrak kulit buah pisang goroho yang ada diperoleh dengan cara menambahkan fase minyak kedalam fase cair kemudian ditambahkan ekstrak. Krim yang ada diuji untuk aktivitas antibakterinya apakah tergolong kuat sedang atau lemah.

\section{Uji Antibakteri}

Hasil dari pengujian antibakteri dapat dilihat pada gambar 1: 


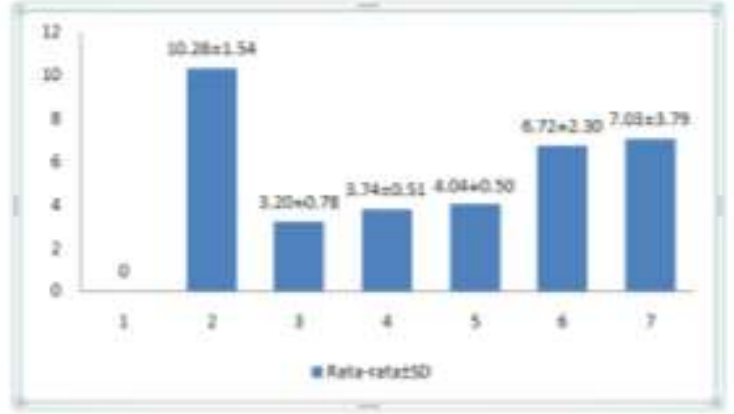

Gambar 1: Grafik pengujian antibakteri

Pengujian antibakteri pada ekstrak etanol kulit pisang goroho terhadap Staphylococcus aureus dilakukan tiga kali pengulangan pada konsentrasi $2,5 \%, 5 \%, 7,5 \%, 10 \%, 12,5 \%$. Pengujian ini perlu dilakukan untuk melihat konsentrasi yang paling terbesar untuk menghambat pertumbuhan bakteri Staphylococcus aureus, ditandai dengan tidak adanya pertumbuhan bakteri pada media NA. Sehingga ketika sudah mendapatkan konsentrasi terbesar itulah yang akan digunakan untuk uji fisik. Pengujian antibakteri dengan menggunakan bakteri Staphylococcus aureus yang dilihat dari daya hambat ini dimaksudkan untuk mengetahui besarnya pelepasan zat aktif dengan mengukur diameter zona hambat pertumbuhan bakteri. Daya hambat menurut Davis dan Stout (1971) terbagi atas : sangat kuat (zona hambat $>20 \mathrm{~mm}$ ), kuat (zona hambat 10-20 mm), sedang (zona hambat 5$10 \mathrm{~mm}$ ) dan lemah (zona hambat $<5 \mathrm{~mm}$ ). Pengujian aktivitas antibakteri ditentukan berdasarkan diameter zona hambat disekitar pencadangan/sumuran media Nutrien Agar (NA). Hasil pengujian yang didapat dengan konsentrasi $2,5 \%, 5 \%, 7,5 \%, 10 \%, 12,5 \%$ menunjukan aktivitas antibakteri dengan adanya zona hambat disekitar sumuran. Diameter zona hambat disekitar sumuran diukur menggunakan jangka sorong dengan cara mengukur secara horizontal dan vertikal kemudian hasil yang didapatkan dikurangi diameter sumuran $7 \mathrm{~mm}$. Krim ekstrak etanol kulit pisang goroho konsentrasi 2,5\% memberikan daya hambat $3,19 \mathrm{~mm}, 5 \%$ memberikan daya hambat $3,74 \mathrm{~mm}, 7,5 \%$ memberikan daya hambat $4,04 \mathrm{~mm}, 10 \%$ memberikan daya hambat $6,72 \mathrm{~mm}$, pada konsentrasi $12,5 \%$ memberikan daya hambat 7,03 $\mathrm{mm}$ dari hasil tersebut dapat dikategorikan memiliki daya hambat yang sedang. kontrol positif memberikan daya hambat $10.27 \mathrm{~mm}$ dan control negatif tidak memberikan daya hambat karena menghasilkan zona hambat $0 \mathrm{~mm}$. dari hasil tersebut dapat dilihat bahwa krim ekstrak etanol kulit pisang goroho dengan konsentrasi $2,5 \%, 5 \%, 7,5 \%, \quad 10 \%$, dan $12,5 \%$ bisa menghambat aktivitas bakteri Staphylococcus aureus dengan menjadikan konsentrasi terbesar yaitu 12,5\% dikarenakan pada konsentrasi 12,5\% memiliki daya hambat yang paling besar. Zona hambat yang terbentuk karena adanya senyawa antibakteri pada kulit pisang goroho senyawa flavonoid, saponin, dan tannin. Dari hasil yang didapat menunjukkan semakin tinggi konsentrasi sediaan krim maka semakin besar daya hambat yang dihasilkan.

\section{Evaluasi Sifat Fisik Krim 1. Uji Organoleptik}

Pengujian organoleptik dilakukan untuk mengetahui bentuk, warna dan bau dari krim yang sudah dibuat. Pengujian ini perlu dilakukan untuk meningkatkan nilai estetika dari suatu sediaan. Hasil Pengujian Organoleptik dapat dilihat di tabel 1:

Tabel 1. Hasil uji organoleptik siklus 0

\begin{tabular}{|c|c|c|c|}
\hline Jenis kim & Bentik & Wama & Ban \\
\hline $\begin{array}{l}\text { Kim etstalk tand kulit teisng gorcho } \\
12,5\end{array}$ & $\begin{array}{l}\text { Setergh h } \\
\text { pedat }\end{array}$ & Hijun & $\begin{array}{l}\text { Khas éstalk kulit } \\
\text { pisang gowoho }\end{array}$ \\
\hline$\frac{\text { Krim elstak etanol kulit pisang gorcho }}{12,5}$ & $\begin{array}{l}\text { Setergah } \\
\text { prabt: }\end{array}$ & Hifles & $\begin{array}{l}\text { Khas ekstrak wult } \\
\text { pisang govoho }\end{array}$ \\
\hline$\frac{\text { Kim elstrak etrnol kulit tisang goroho }}{12,5}$ & $\begin{array}{l}\text { Setegah } \\
\text { pedat }\end{array}$ & Hijul & $\begin{array}{l}\text { Khas elstralk lulit } \\
\text { pisang gucho }\end{array}$ \\
\hline
\end{tabular}

\section{Uji Homogenitas}

Pengujian homogenitas dilakukan untuk melihat homogenitas krim yang dibuat. Pengujian yang dilakukan dengan cara dioleskan pada sekeping kaca. Krim dikatakan homogen jika tidak terlihat adanya butiran kasar. Hasil Pengujian Homogenitas Krim Ekstrak Etanol Kulit Pisang Goroho dapat dilihat pada tabel 2:

Tabel 2. Hasil uji homogenitas siklus 0

\begin{tabular}{|c|c|}
\hline Jenis krim & Homogenitas \\
\hline 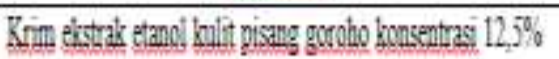 & Homogen \\
\hline 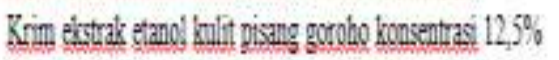 & Honogen \\
\hline Krim ektrable etano, knili piang guoho konsentras $12,5 \%$ & Honogen \\
\hline
\end{tabular}

3. Uji pH

Pengujian $\mathrm{pH}$ sediaan dilakukan dengan menggunaka $\mathrm{pH}$ meter.pH sediaan krim harus 
sesuai dengan $\mathrm{pH}$ kulit yaitu 4,5-6,5. Hasil pengukuran $\mathrm{pH}$ dapat dilihat pada tabel 3 .

Tabel 3. Hasil uji pH siklus 0

\begin{tabular}{cc}
\hline Pengulangan & $\mathrm{pH}($ Siklus 0$)$ \\
\hline 1 & 5.12 \\
2 & 5.15 \\
3 & 5.46 \\
\hline Rata-rata $\mathrm{SD}$ & $5.243 \pm 0.188$ \\
\hline
\end{tabular}

\section{Uji Daya Lekat}

Pengujian daya lekat sediaan dilakukan dengan cara krim diletakkan pada satu sisi kaca objek dengan sisi bawahnya telah dipasangkan tali untuk mengikat beban. Kemudian ditempelkan pada kaca objek yang lain. Beban yang digunakan adalah 50 g. Kemudian diamati waktu yang dibutuhkan beban tersebut untuk memisahkan kedua kaca tersebut. Hasil pengukuran daya lekat dapat dilihat pada tabel 4 .

Tabel 4. Hasil uji daya lekat siklus 0

\begin{tabular}{cc}
\hline Pengulangan & Daya lekat (Siklus 0) \\
\hline 1 & 6.23 \\
2 & 6.63 \\
3 & 9.12 \\
\hline Rata-rata \pm SD & $7.327 \pm 1.566$ \\
\hline
\end{tabular}

\section{Uji Daya Sebar}

Pengujian daya sebar dilakukan untuk menjamin tersebarnya krim ketika diaplikasikan ke kulit.Pengukuran daya sebar dilakukan dengan mengukur diameter sebar krim ketika ditimpa beban $100 \mathrm{~g}$ dan diamkan selama 1menit hingga diameternya konstan.Hasil penelitian daya sebar dapat dilihat pada tabel 5 .

Tabel 5. Hasil uji daya sebar siklus 0

\begin{tabular}{cc}
\hline Pengulangan & Dava sebar (Siklus 0) \\
\hline 1 & 4.7 \\
2 & 4.7 \\
3 & 4.7 \\
\hline Rata-rata \pm SD & $4.7 \pm 0$ \\
\hline
\end{tabular}

\section{Stabilitas}

Pengujian stabilitas terhadap sediaan krim ekstrak kulit pisang goroho agar diketahui kelayakan dan kestabilan krim. Pengujian fisik krim meliputi pengujian organoleptik, pengujian homogenitas, pengujian $\mathrm{pH}$, pengujian daya sebar, pengujian daya lekat, cycling test.

Uji organoleptik diuji kembali selama proses cycling test untuk melihat kestabilan dan membandingkan hasilnya sebelum cycling test (siklus 0) dan selama cycling test (siklus1-6). Hasil uji organoleptik sebelum dan setelah cycling test dapat dilihat pada tabel 6 .

Tabel 6. Hasil uji organoleptik sebelum dan selama cycling test

\begin{tabular}{|c|c|c|c|}
\hline Jenishin & Bentill & Wame & Ben \\
\hline 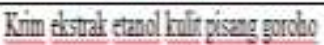 & Stragah & & Khas etandlint \\
\hline 125 & padat & HIIIII & pisang \\
\hline Kin thtal thal hil piseng gurdo & Settangh & म" & Khas etand lalit \\
\hline 125 & padat & Iylat & pisang \\
\hline 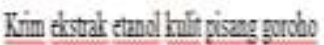 & Setrogh & $\pi$ & Thes etand hit \\
\hline 12.5 & padet & Hylay & pisang \\
\hline
\end{tabular}

Pengujian organoleptik meliputi bentuk, warna dan bau. Krim yang dihasilkan memiliki bentuk setengah padat yang merupakan karakteristik dari krim pada umumnya. Warna hijau merupakan warna dari ekstrak kulit pisang goroho yang telah tercampur secara homogen dengan basis krim. Dalam krim juga tercium aroma dari ekstrak kulit pisang goroho, untuk basis krimnya sendiri tidak berbau. Pengujian organoleptik sebelum cycling test (siklus 0) dan selama cycling test (siklus 1-6) tidak mengalami perubahan baik warna, bau dan bentuk dari sediaan. Sehingga krim ini memenuhi standar uji stabilitas.

Pengujian homogenitas dilakukan uji cycling test untuk mengetahui kestabilan krim agar tetap homogen selama dipengaruhi oleh suhu. Hasil uji homogenitas sebelum dan selama cycling test dapat dilihat pada tabel 7 .

Tabel 7. Hasil uji homogenitas sebelum dan selama cycling test

\begin{tabular}{|c|c|c|}
\hline Percobaan & Sebelim groding test silkis 0 & Selama cring test sikus $1-6$ \\
\hline 1 & Hornogen & Homogen \\
\hline 2 & Homogen & Honogen \\
\hline 3 & Honogen & Honogen \\
\hline
\end{tabular}


Homogenitas merupakan faktor yang penting karena dapat berpengaruh terhadap distribusi obat. Sediaan dikatakan homogen bila terdapat persamaan warna dan tidak adanya partikel atau bahan kasar yang dapat diraba (Syamsuni, 2005). Uji homogenitas baik sebelum cycling test (siklus 0) dan selama cycling test (siklus 1-6) struktur krim menunjukkan susunan yang homogen. Krim juga tidak terjadi pemisahan antara fase air dan fase minyak, sehingga memenuhi standar uji kestabilan.

Uji pH pada krim untuk mengetahui kadar asam dan basa dari sediaan krim. Nilai $\mathrm{pH}$ untuk sediaan topical harus sesuai dengan $\mathrm{pH}$ kulit yaitu 4,5-6,5. Pengujian $\mathrm{pH}$ pada sediaan krim menggunakan $\mathrm{pH}$ meter dengan memasukkan alat pH meter kedalam krim yang telah dibuat. Hasil uji $\mathrm{pH}$ dapat dilihat pada gambar 2 .

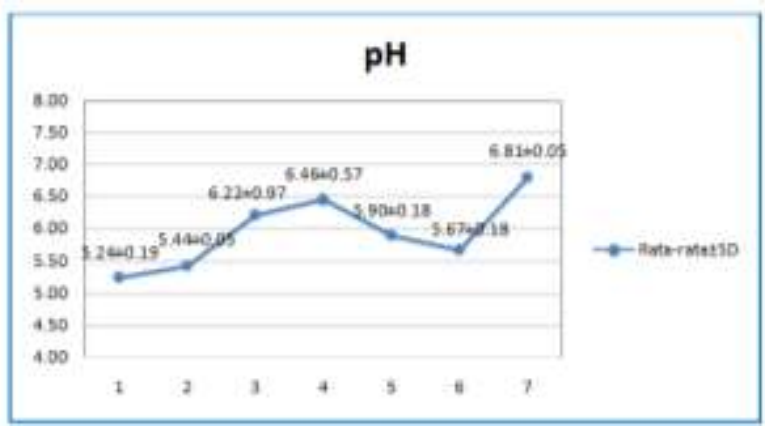

Gambar 2: Grafik uji stabilitas $\mathrm{pH}$

Hasil statistika uji pH dilakukan dengan menggunakan Independent $T$ test 'untuk membandingkan $\mathrm{pH}$ krim ekstrak kulit pisang goroho pada dari siklus 0 sampai pada siklus 6. tidak ada perbedaan bermakna sebelum dan sesudah cycling test jika nilai signifikasinya (2-tailed) $\geq 0,05$ dan adanya perbedaan bermakna sebelum dan sesudah cycling test jika nilai signifikasinya $\leq 0,05$ dan dari hasil data statistika $\mathrm{pH}$ nilai signifikasinya 0,003 atau $\leq 0,05$ jadi dapat disimpulkan bahwa uji pH krim ekstrak kulit pisang goroho pada kosentrasi $12,5 \%$ memiliki perbedaan bermakna sebelum dan sesudah cycling test.

Pengujian daya sebar merupakan pengujian yang dilakukan untuk mengetahui kemampuan penyebaran krim selama proses cycling test agar mudah diaplikasikan. Hasil uji daya sebar dapat dilihat pada gambar 3 .

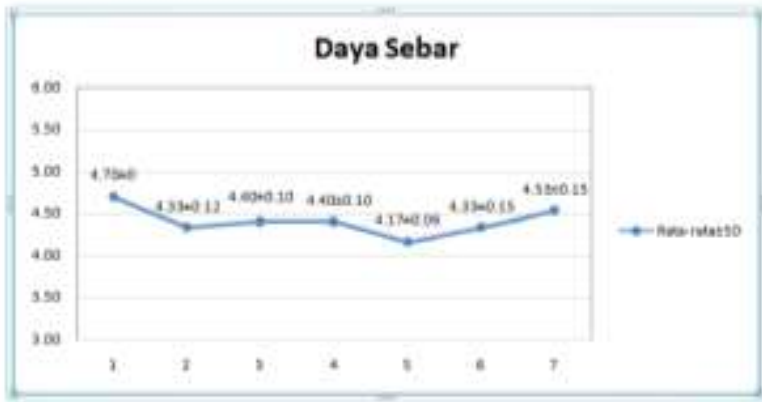

Gambar 3: Grafik uji stabilitas daya sebar

Hasil ini juga tidak memenuhi standar daya sebar sediaan krim. Selama proses cycling test hasil uji daya sebar mengalami kenaikan dan penurunan nilai karena dipengaruhi oleh suhu pada saat penyimpanan. Dari hasil uji daya sebar dengan menggunakan beban yang sama terlihat sedikit perubahan, diketahui semakin tinggi konsentrasi penambahan ekstrak krim maka semakin rendah daya sebar krim, karena semakin kental konsistensinya, maka semakin kecil daya sebar yang dihasilkan. Uji daya sebar krim baik sebelum cycling test (siklus 0) dan sesudah cycling test (siklus 6) keduanya tidak memenuhi standar daya sebar krim. Tetapi dari nilai sebelum cycling test (siklus 0) dan selama cycling test (siklus 1 - siklus 6) konsistensi krim tetap bagus karena hasil nilai pengujian tidak berbeda jauh antar siklus. Proses uji stabilitas memiliki daya sebar krim yang stabil yaitu dilihat dari hasil nilai statistika yang menunjukan nilai Sig(2-tailed) yaitu 0,199 dimana nilai ini >0.05 yang berarti tidak ada perbedaan yang bermakna sebelum dan sesudah cycling test.

Uji daya lekat dilakukan pengujian stabilitas untuk melihat kestabilan daya lekat krim selama proses cycling test. Hasil uji daya lekat krim dapat dilihat pada gambar 4.

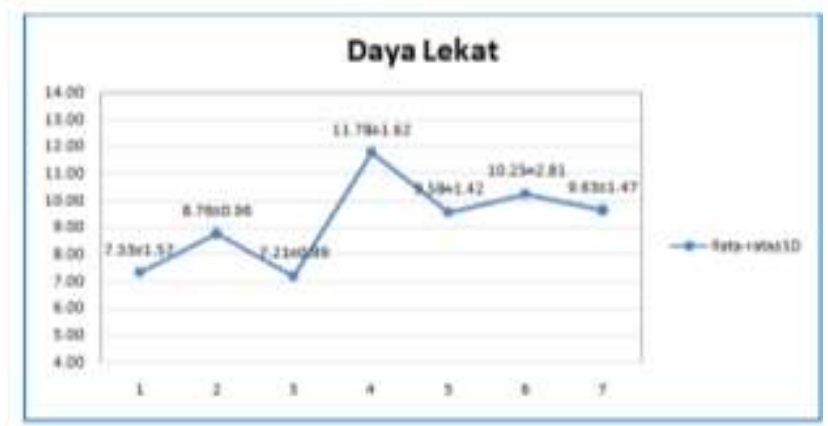

Gambar 4: Grafik stabilitas daya lekat 
Hasil pengujian daya lekat mengalami kenaikan dan penurunan karena dipengaruh oleh suhu saat penyimpanan. Hal ini sama halnya dengan pengujian daya sebar dimana suhu mempengaruhi viskositas dari krim. Semakin rendah viskositas suatu sediaan maka semakin besar daya penyebarannya tetapi daya melekatnya semakin turun. Tetapi hasil uji daya lekat selama cycling test memenuhi standar uji. Nilai uji daya lekat krim sebelum cycling test (siklus 0) dan

\section{KESIMPULAN}

Ekstrak kulit pisang goroho dapat diformulasikan menjadi sediaan krim dengan konsentrasi $12,5 \%$ dan memenuhi syarat parameter uji yaitu uji organoleptik, homogenitas, PH dan daya lekat namun tidak memenuhi syarat uji daya sebar. Berdasarkan hasil uji stabilitas, $\mathrm{pH}$ menunjukkan ada perbedaan bermakna, daya sebar dan daya lekat krim tidak menunjukkan adanya perbedaan bermakna sehingga bisa dikatakan krim yang dibuat merupakan krim yang stabil dan berdasarkan uji efektivitas antibakteri sediaan krim ekstrak etanol kulit pisang goroho dapat memberikan efek antibakteri terhadap bakteri Staphylococcus aureus dengan diameter rata-ratanya pada konsentrasi $12,5 \%(7,03 \mathrm{~mm})$.

\section{SARAN}

Disarankan kepada penelitian selanjutnya untuk perlu dilakukan evaluasi fisik yang belum dilakukan dalam penelitian ini yaitu uji viskositas, dan uji Iritasi.

\section{DAFTAR PUSTAKA}

Alhabsyi, Dita., Suryanto, E. dan Wewengkang, D. 2013. Analisis Fitokimia dan Uji Aktivitas Antioksidan dan Tabir Surya pada Ekstrak Kulit Buah Pisang Goroho (Musa acuminafe L.). Pharmacon. 3(5):2302 - 2493.

Davis, W. W., Stout, T. R. 1971. Disc Plate Methods of Microbiology. 22(4):659-665.

Dewi, R.K. 2010. Optimasi Formulasi Mikroemulsi Sediaan Hormon Testosteron Undekanoat [Skripsi]. Fakultas Matematika dan Ilmu Pengetahuan Alam, Universitas Islam Negeri Syarif Hidayatullah, Jakarta.

Edy, H.J., dan Parwanto, M.L..E. 2019. Pemanfaatan Tanaman Tagetes erecta Linn. sesudah cycling test (siklus 6) keduanya memenuhi standar daya lekat krim yaitu $>4$ detik. Dari hasil ini krim ekstrak etanol kulit buah Pisang Goroho mempunyai nilai daya lekat yang stabil selama proses penyimpanan. Hasil statistika daya lekat krim sebelum dan sesudah cycling test memiliki nilai Sig (2-tailed) $>0.05$ yaitu 0.137 yang berarti tidak ada perbedaan yang bermakna sebelum dan sesudah cycling test.

dalam Kesehatan. Jurnal Biomedika dan Kesehatan 2(2):77-80.

Edy, H.J., Marchaban., Wahyuono, S., Nugroho, A.E. 2016. Formulasi dan Uji Sterilitas Hidrogel Herbal Ekstrak Etanol Daun Tagetes erecta L. Pharmacon 5(2):9-16.

Edy, H.J., Marchaban., Wahyuono, S., Nugroho, A.E. 2017. Characterization and Evaluation of Bioactive Compounds of Extract Ethanol Tagetes erecta L by GC-MS. International Journal of ChemTech Research 10(2):172-175.

Edy, H.J., Marchaban., Wahyuono, S., Nugroho, A.E. 2017. Formulation and Evaluation of Hydrogel Containing Tagetes erecta L. Leaves Ethanolic Extract. International Journal of Current Innovation Research 3(3):627-630.

Edy, H.J., Marchaban., Wahyuono, S., Nugroho, A.E. 2019. Pengujian Aktivitas Antibakteri Hidrogel Ekstrak Etanol Daun Tagetes erecta L. Jurnal MIPA 8(3):96-98.

Engelina, N.G., 2013. Optimasi Krim Sarang Burung Walet Putih (Aerodramus Fuciphagus) Tipe M/A dengan Variasi Emulgator Sebagai Pencerah Kulit Menggunakan Simplex Lattice Design. J. Mhs. Farm. Fak. Kedokteran. UNTAN 1.

Erawati, E., Pratiwi, D., Zaky, M. 2016. Pengembangan Formulasi dan Evaluasi Fisik Sediaan Krim Ekstrak Etanol 70\% Daun Labu Siam. Yogyakarta, Pustaka Pelajar.

Kinho, J., Arini, D.I.D., Tabba, S., Kama, H., Kafiar, Y., Shabri, S., Karundeng, M.C. 2011. Tumbuhan Obat Tradisional di Sulawesi Utara Jilid I. Manado, Balai Penelitian Kehutanan Manado. 
Lubis, E.S dan Reveny, J. 2012. Pelembab Kulit Alami Dari Sari Buah Jeruk Bali [Citrus Maxima (Burm). Osbeck]. Journal of Pharmaceutics and Pharmacology 1(2), 104111.

Nugroho, A.K. 2015. Aplikasi Komputasi Dan Modeling Berbasis Populasi Dalam Pengembangan Formulasi Sediaan Transdermal. Jakarta.

Parwanto, M.L.E., Mahyunis., Senjaya, H., Edy, Parwanto, M.L.E., Senjaya, H., Edy, H.J. 2013. Formulasi Salep Antibakteri Ekstrak Etanol Daun Tembelekan (Lantana camara L.). Pharmacon 1 (1): 104-108.

Simangunsong, F.M.P., Mulyani, S., Hartiati, A. 2018. Evaluasi Karakteristik Krim Ekstrak Kunyit (Curcuma domestica) Pada Berbagai Formulasi. J.Rekayasa dan Agroindustri 6, 1121. Bandung.

Syamsuni, H.A. 2005. Ilmu Resep. Jakarta: EGC.

Tina, R., Rani, M., Soraya, R.M. 2009. Penelusuran Senyawa Aktif Ekstrak Daun Sukun (Artocarpus altilis) Terhadap Staphylococcus aureus, Microsporum gypseum dan Candida albicans. Laporan Akhir Penelitian Hibah Bersaing Tahun Ke-1. Bandung: Departemen Pendidikan Nasional Unpad Fakultas Farmasi. 